\title{
The Value of Somatostatin Receptor Imaging with In- I I I Octreotide and/or Ga-68 DOTATATE in Localizing Ectopic ACTH Producing Tumors
}

\author{
Ektopik ACTH Sendromu'nda In- I I Oktreotid ve/veya Ga-68 DOTATATE \\ Görüntülemenin Katkısı
}

\author{
Zeynep Gözde Özkan', Serkan Kuyumcu1, Deniz Balköse², Berker Özkan³, Nihat Aksakal4, Ebru Yılmaz', Yasemin Şanlı1, \\ Cüneyt Türkmen', Ferihan Aral5, Işık Adalet ${ }^{1}$ \\ IIstanbul University Istanbul Medical Faculty, Nuclear Medicine Department, Istanbul, Turkey \\ 2Mehmet Akif Ersoy Thoracic and Cardiovascular Surgery Research and Education Hospital, Nuclear Medicine Department, Istanbul, Turkey \\ 3 Istanbul University Istanbul Medical Faculty, Thoracic Surgery Department, Istanbul, Turkey \\ ${ }^{4}$ Istanbul University Istanbul Medical Faculty, General Surgery Department, Istanbul, Turkey \\ 5 Istanbul University Istanbul Medical Faculty, Endocrinology and Metabolism Department, Istanbul, Turkey
}

\begin{abstract}
Objective: We aimed to evaluate the value of somatostatin receptor imaging (SRI) with In-111 octreotide and Ga-68 DOTATATE in localizing ectopic ACTH producing tumors.

Methods: Nineteen patients who had In-111 octreotide somatostatin receptor scintigraphy (SRS) and/or Ga-68 DOTATATE PETCT to localize ectopic ACTH producing tumors between the years 2000 and 2012 were included retrospectively in our study. The results of SRI were compared with clinical onset, radiological findings and surgical data of the patients.

Results: Sixteen In-111 octreotide SRS and five Ga-68 DOTATATE PET-CT were performed in 19 patients. In eight out of 19 patients, ectopic ACTH secretion site could be detected. In five patients, SRS showed pathologic uptake. In four of these patients, surgery revealed pulmonary carcinoid tumors and in one patient pancreatic neuroendocrine tumor. In one patient, Ga-68 DOTATATE PET-CT revealed pathologic uptake in lung nodule which came out to be pulmonary carcinoid tumor. In another patient who had resection of metastases of atypical carcinoid tumor prior to scans, new metastatic foci were detected both with SRS and Ga-68 DOTATATE PET-CT imaging. In one patient, although SRS was negative, CT which was performed three years later showed a lung nodule diagnosed as pulmonary carcinoid tumor. In 11 patients, ectopic ACTH secretion site could not be detected. In 10 of those patients, scintigraphic and radiological imaging did not show any lesions and in one patient, Ga-68 DOTATATE PET-CT was false positive.

Conclusion: SRI has a complementary role with radiological imaging in localizing ectopic ACTH secretion sites. PET-CT imaging with Ga-68 peptide conjugates is a promising new modality for this indication.

Key words: Cushing syndrome, ectopic ACTH Syndrome, indium-111-octreotide, somatostatin receptor, scintigraphy, gallium radioisotopes, positron-emission tomography/computed tomography

Özet

Amaç: Çalışmamızda, In-111 oktreotid sintigrafisi ve Ga-68 DOTATATE PET-BT ile yapılan somatostatin reseptör görüntülemenin (SRG) ektopik ACTH sendromu tanısındaki katkısını incelemeyi amaçladık.

Yöntemler: Ektopik ACTH salınım odağının saptanması amacıyla bölümümüzde 2000-2012 yılları arasında In-111 oktreotid sintigrafisi ve/veya Ga-68 DOTATATE PET-BT çekimi yapılan 19 hasta retrospektif olarak incelendi. Tüm çekim sonuçları, radyolojik görüntülemeler, histopatolojik bulgular ve klinik takip bilgileri ile birlikte değerlendirildi.
\end{abstract}

Address for Correspondence: Zeynep Gözde Özkan MD, İstanbul University Istanbul Medical Faculty, Nuclear Medicine Department, İstanbul, Turkey Phone: +90 21241420 00/35085 E-mail: zgozdeozkan@yahoo.com Received: 21.04.2013 Accepted: 19.06.2013 
Bulgular: Ondokuz hastada 16 In-111 oktreotid sintigrafisi, beş Ga-68 DOTATATE PET-BT çekimi yapılmıştır. Ondokuz hastanın sekizinde ektopik ACTH salgılanan odak saptanmıştır. In-111 oktreotid sintigrafisi pozitif olup opere edilen toplam beş hastanın dördünde pulmoner karsinoid tümör, bir hastada pankreatik nöroendokrin tümör saptanmıştır. Ga-68 DOTATATE PET-BT görüntülemesinde akciğerdeki nodülde tutulum saptanmış ve opere edilmiş olan hastada patoloii sonucu atipik karsinoid tümör olarak raporlanmıştır. Diğer hastada ise atipik karsinoid tümör metastazları çekimlerden önce rezeke edilmiş, yapılan In-111 oktreotid sintigrafisi ve Ga-68 DOTATATE PET-BT görüntülemede ise yaygın metastatik lezyonlar saptanmıștır. Ektopik ACTHH salgılanan odağın bulunabildiği son hastada ise In-111 oktreotid sintigrafisi negatif bulunmuş, takiplerde üç yıl sonra çekilen toraks BT'de izlenen nodülün rezeksiyon sonucu pulmoner karsinoid tümör gelmiştir. Onbir hastada ektopik ACTH salgılanan odak bulunamamıştır. Bu hastalardan 10'unda sintigrafik ve radyolojik görüntülemelerde odak saptanmazken, bir hastada ise Ga-68 DOTATATE PET-BT sonucu yalancı pozitif olarak değerlendirimiştir.

Sonuç: Ektopik ACTH salınım odağının tespitinde SRG radyolojik yöntemlerle tamamlayıcı bir role sahiptir. Ga-68 peptid bileşikleri ile yapılan PET-BT, bu konuda umut vaat eden yeni bir modalitedir.

Anahtar kelimeler: Cushing sendromu, ektopik ACTH sendromu, indiyum-111-oktreotid, somatostatin reseptörü, sintigrafi, Galyum Radyoizotop, pozitron-emisyon tomografi/bilgisayarlı tomografi

\section{Introduction}

Hypersecretion of hormones from adrenal cortex causes a complex cascade of effects which is called Cushing's syndrome. Most of the abnormalities of Cushing's syndrome are caused by abnormal amounts of cortisol (1). Cushing's syndrome is classified into 2 types as ACTH-dependent and ACTH-independent. Excess amount of cortisol is the result of primary adrenal overproduction in the ACTH-independent type and ACTH levels are low or in undetectable amounts. In the ACTH-dependent type, there is overproduction of ACTH either from pituitary adenoma (Cushing's disease) or hypothalamic-pituitary dysfunction or ectopic secretion from tumors (1). Ectopic ACTH secretion accounts for approximately $15-20 \%$ of ACTH-dependant Cushing's syndrome (2).

Localization of ACTH secreting tumors is a challenging process. Ilias et al reported that in 19\% of their patients, a tumor could not be identified despite extensive evaluation (3). Hernandez et al managed to localize the source of ectopic ACTH secretion in $62.5 \%$ of their patients by using multiple imaging modalities (4). Although there are controversial results about its performance in the literature, somatostatin receptor scintigraphy (SRS) with In-111 octreotide had been used to detect ectopic ACTH secreting tumors $(2,3,4,5,6,7,8,9,10,11,12)$. Ga-68 peptide conjugates had begun to be used recently for the similar indications with In-111 octreotide. There are several case reports about detection of ectopic ACTH secreting tumors with Ga-68 peptide conjugates $(13,14,15)$.

In this study, the value of somatostatin receptor imaging (SRI) with In-111 octreotide and Ga-68 DOTATATE in detection of ectopic ACTH secretion was evaluated.

\section{Materials and Methods}

\section{Patients}

Twenty-nine patients with suspicion of ectopic ACTH syndrome who were referred to our department for SRS with In-111 octreotide between 2000 and 2011 (24 patients, 29 scans) and for Ga-68 DOTATATE PET-CT between 2011 and 2012 (8 patients, 9 scans) were retrospectively evaluated. Informed consent of every patient was obtained prior to imaging. Ten patients were excluded from the study due to pituitary adenomas which were detected with cranial MRI during follow-up. SRS with In-111 octreotide in 16 patients and Ga-68 DOTATATE PET-CT scans in five patients were performed in a total of 19 patients. In two patients, both In-111 SRS and Ga-68 DOTATATE PET-CT were done.

There were 13 female and six male patients. The ages ranged between 14 and 61 years. The mean age was 37,8 years. Two patients had pituitary surgery, three patients had bilateral adrenalectomy, one patient had pituitary surgery and bilateral adrenalectomy, one patient had mediastinal mass resection before In-111 octreotide SRS or Ga-68 DOTATATE PET-CT was performed.

\section{Patient Preparation}

For patients who were under somatostatin therapy, In-111 octreotide SRS or Ga-68 DOTATATE PET-CT was performed four weeks after the therapeutic injection of somatostatin. The patients were asked to use laxatives for bowel cleaning and to eat a light diet before In-111 octreotide administration and during imaging period. Oral contrast agent was given to patients for Ga-68 DOTATATE PET-CT.

\section{Somatostatin Receptor Scintigraphy}

Five $\mathrm{mCi}$ of $\mathrm{In}-111$ octreotide was administered to patients intravenously. Imaging was performed by either Siemens ECAM or ADAC Vertex Plus Gama-camera. Whole body image acquisition was performed in anterior and posterior positions $(10 \mathrm{~cm} / \mathrm{min})$ four hours after injection. Subsequent anterior and posterior static images (106 counts) of the thorax and abdomen were also performed. Late static images of thorax and abdomen were acquired 24 hours after injecton as well as SPECT image acquisition. SPECT images were acquired according to the following parameters: 64 frames, $128 \times 128$ matrix, $360^{\circ}$ rotation, 40 
seconds/frame. Image acquisition was also performed at 48 hours when necessary. CT of the appropriate regions were also performed on spiral 4 slice CT (CT component of Biograph ${ }^{\mathrm{TM}}$ TruePoint ${ }^{\mathrm{TM}}$ PET-CT) with a slice thickness of $4 \mathrm{~mm}$ in 7 patients. CT images and reconstructed SPECT images were evaluated after fusion images were rendered using Siemens SYNGOTM software.

\section{Ga-68 DOTATATE PET-CT Imaging}

Ga-68 DOTATATE was prepared in-house on a fully automated system (Eckert \& Ziegler Eurotope, Berlin, Germany). The images were obtained on a dedicated PET/ CT scanner (Biograph ${ }^{\text {TM }}$ TruePoint ${ }^{\mathrm{TM}}$ PET/CT), 60 min after intravenous injection of 3-4 mCi of Ga-68 DOTATATE . CT acquisition was performed on spiral four slice CT with a

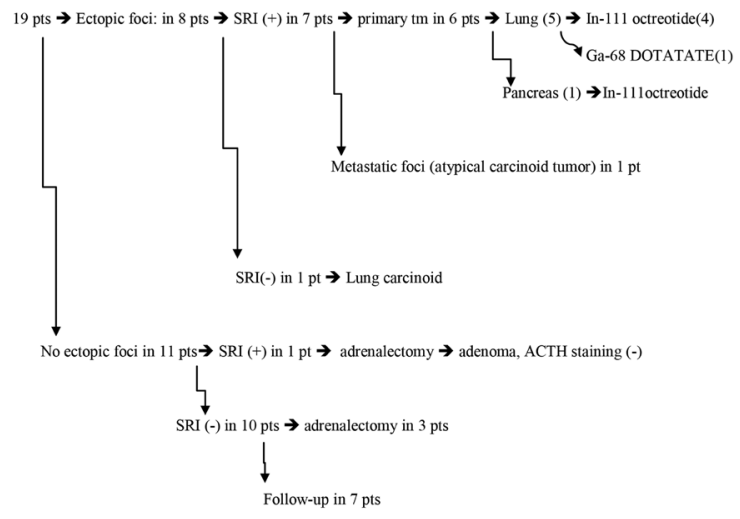

Figure 1. Summary of patient outcomes

SRI: Somatostatin receptor imaging

Pt: patient

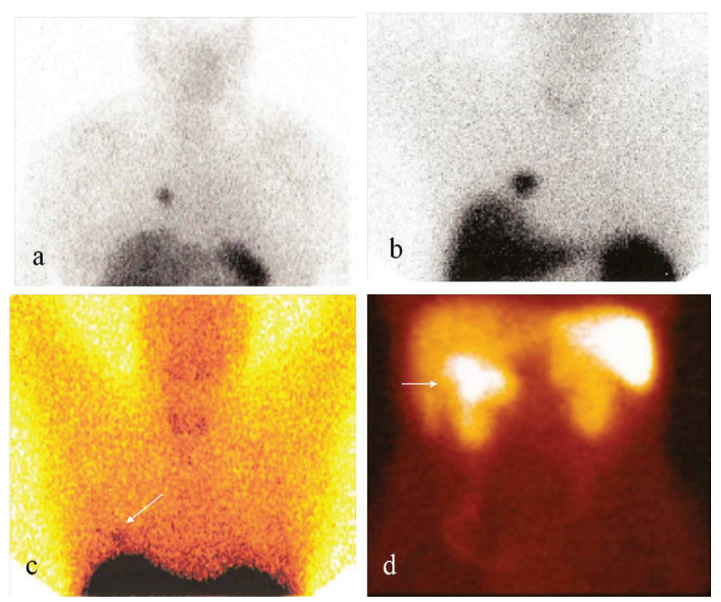

Figure 2. Planar images of In-111 octreotide SRS of 4 patients are shown: Pulmonary carcinoid tumors (A-C) and pancreatic neuroendocrine tumor (D) slice thickness of $4 \mathrm{~mm}$. After transmission scan, 3D PET acquisition was taken for 4 min per bed position for 6-8 bed positions. CT-based attenuation correction of the emission images was employed. PET images were reconstructed by iterative method ordered subset expectation maximization ( 2 iterations and 8 subsets) with filter size of $5 \mathrm{~mm}$. After completion of PET acquisition, the reconstructed attenuation corrected PET images, CT images and fused images of matching pairs of PET and CT images were available for review in axial, coronal, and sagittal planes and in maximum intensity projections three dimensional cine mode.

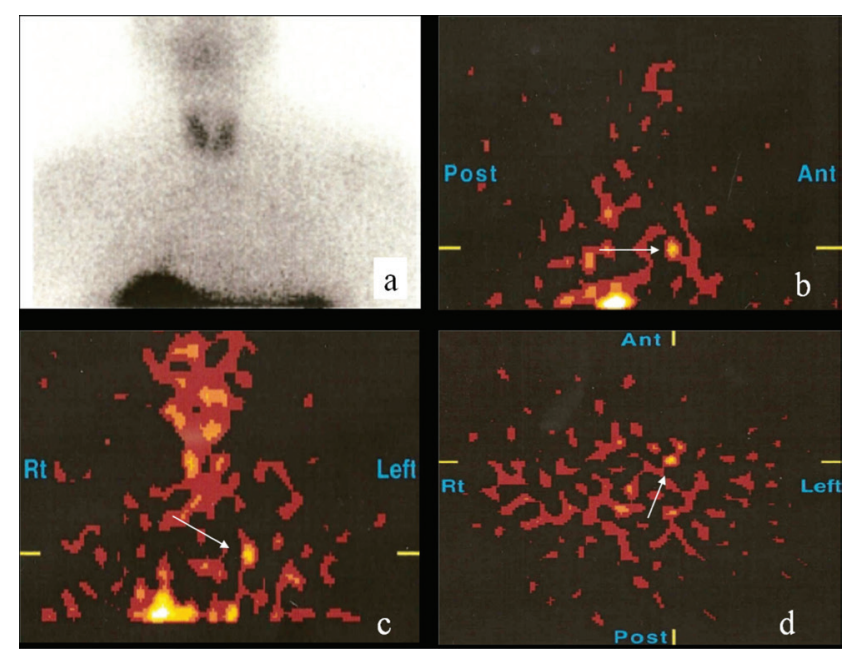

Figure 3. Planar and SPECT images of In-111 octreotide SRS of a patient with pulmonary carcinoid tumor. Although the planar image is negative (A), in sagittal (B), coronal (C) and axial (D) SPECT images the lesion can be seen

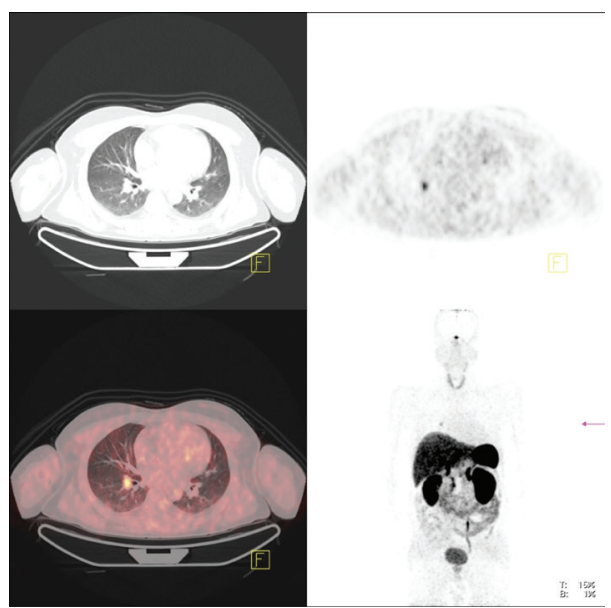

Figure 4. The centrally located pulmonary nodule in right lung lower lobe cannot be detected easily in CT image, but there is high Ga-68 DOTATATE uptake in PET image. The nodule can be easily detected in PET-CT fusion image. 


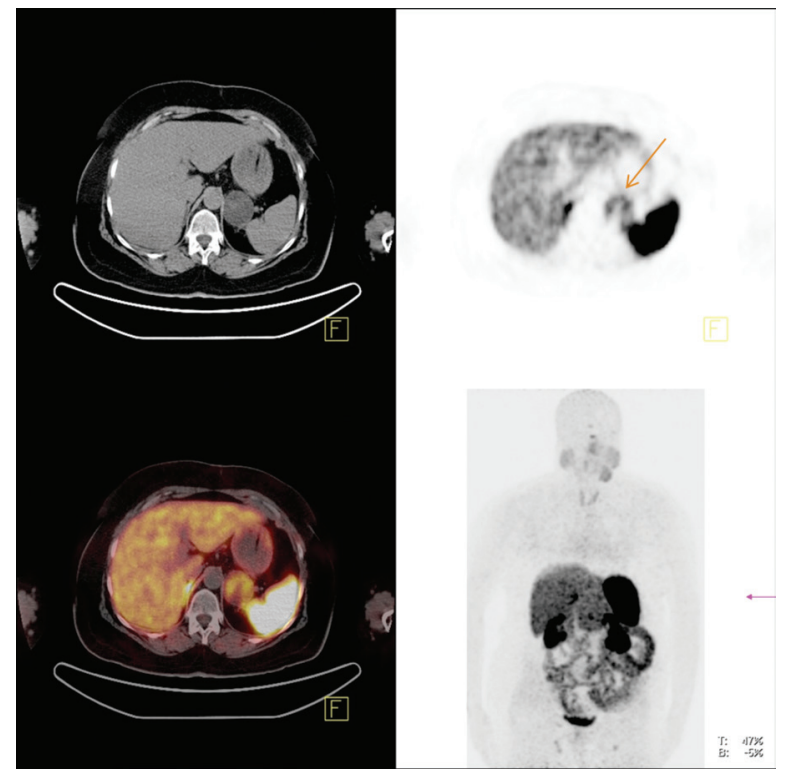

Figure 5. The moderate Ga-68 DOTATATE uptake in the left adrenal lesion led to false positive interpretation of the image as the site of ectopic ACTH secretion, but the pathology revealed adrenal adenoma without ACTH staining.

\section{Evaluating SRS and PET-CT Images}

A positive scan was defined as significant accumulation of tracer, based on visual assessment. The images were reviewed for areas of abnormally increased tracer uptake other than physiological uptakes in thyroid, spleen, liver, kidneys, pituitary gland, bowel and bladder by an experienced nuclear medicine physician. For SRS images, abnormal uptakes on the early static images were followed on the late static images, which were acquired at 24 hours and if the abnormal uptake remained or its intensity was increased, it was considered as pathological.

\section{Patient Evaluation}

The results of In-111 octreotide SRS and Ga-68 DOTATATE PET-CT were evaluated in comparison to clinical onset, radiological findings and postsurgical histopathological examination of the patients.

\section{Results}

In eight out of 19 (42.1\%) patients, ectopic ACTH secretion sites were detected. In six patients, pulmonary carcinoid tumor and in one patient pancreatic neuroendocrine tumor was the reason of ectopic ACTH secretion. In the last patient, metastatic foci of atypical carcinoid tumor of the unknown origin were the sites of ACTH secretion. The summary of patients' outcome is given in Figure 1. In seven of these eight patients (87.5\%), SRI were positive.
In four patients with pulmonary carcinoid tumors, there were pathological In-111 octreotide uptakes in the tumors (Figure $2 A-C$ ). In one of these patients, there was no pathological In-111 octreotide uptake in the planar images, but only in SPECT images (Figure 3). Other 3 patients had In-111 octreotide uptake on both planar and SPECT images. In all of these patients, there were nodules which corresponded to these uptake sites on CT images performed before SRS. All patients underwent surgery and postsurgical histopathological examination revealed pulmonary carcinoid tumors. Size of the tumors ranged between 0.8 to 2 centimeters. In another patient with pulmonary carcinoid tumor, there was no pathological In111 octreotide uptake on SRS. A follow-up CT which was peformed three years after SRS revealed a one centimeter nodule in left lung upper lobe. The nodule was resected and came out to be a carcinoid tumor. In the last patient with pulmonary carcinoid tumor, there was high Ga-68 DOTATATE accumulation in the nodule which was $1,3 \mathrm{~cm}$ in diameter, located centrally at right lung lower lobe (Figure 4). The CT images performed before Ga-68 DOTATATE PET$C T$ was evaluated as negative for this suspicious lesion. The patient had a right lung lower lobe resection and the pathology specimen confirmed an atypical carcinoid tumor.

In the patient with pancreatic neuroendocrine tumor, there was a mass of $5 \mathrm{~cm}$ diameter detected in MR imaging prior to SRS, located between duodenum, pancreatic head and mesenteric vascular bed. There was pathological In-111 octreotide uptake in the tumor (Figure 2D). This patient underwent pancreatoduodenectomy and surgical resection material revealed a neuroendocrine tumor.

The last patient with positive SRI was diagnosed with metastatic atypical carcinoid tumor following resection of mediastinal mass and lymph nodes. SRS was performed in order to localize other ectopic sources of ACTH since the clinical symptoms of the patient did not improve in the postsurgical period. Planar and SPECT-CT images of SRS demonstrated faint uptake of In-111 octreotide in metastatic lymph nodes and bone lesions. Patient underwent chemotherapy but her clinical status worsened in long term follow up. Ga-68 DOTATATE PET-CT imaging had showed progression of the disease.

In 11 patients, ectopic ACTH secretion site could not be localized. In 10 of these patients there was neither any pathologic tracer uptake in SRI nor any lesions in radiologic imaging. In seven of these 10 patients, the clinical onset of the disease was mild and they were followed-up. In the remaining three patients, the severe clinical onset 
of the disease led to bilateral adrenalectomy. In the last patient, a mass was detected in left adrenal gland, $4 \mathrm{~cm}$ in diameter on CT images. There was a moderate Ga-68 DOTATATE uptake in this lesion (Figure 5). Although the ectopic ACTH secretion was thought to be from this lesion, the adrenalectomy material revealed an adenoma without ACTH staining. ACTH level of the patient did not decrease after the operation. Ga-68 DOTATATE PET-CT result is accepted to be false positive in this patient.

\section{Discussion}

Evaluating patients with suspected ectopic ACTH production is a challenging issue. The main problem is the localization of the ACTH secreting tumor. In our patient group, there were 19 patients with the diagnosis of ectopic Cushing's syndrome, but only in eight patients (42.1\%), the foci of the disease could be detected. In the literature there are varying results. Ilias et al reported that in 19\% of their patients, a tumor could not be identified (3), whereas Hernandez et al could localize the tumors in $62.5 \%$ of their patients (4).

There are controversial results about the performance of SRI in the literature. In our study, seven patients out of eight (\%87.5) had positive SRI, either with In-111 octreotide or Ga-68 DOTATATE. Zemskova et al reported the sensitivity of In-111 octreotide SRS for detection of the ectopic ACTH source as $57 \%$, whereas the positive predictive value was $79 \%$ (11). Ejaz et al reported a sensitivity of $60 \%$, Loli et al $67 \%$, llias et al. $49 \%(3,8,12)$. In the study of De Herder et al., SRS have succesfully visualized ectopic ACTH producing tumors in eight of the 10 patients (5). In another study by Tsagarakis et al., in eight of 11 patients, ectopic ACTH producing tumors were succesfully detected by SRS (7). On the other hand, Torpy et al reported that only six SRS of 18 patients were positive (6). Similarly, in the study of Tabarin et al., only four patients out of 12 had positive SRS (2). llias et al stated that SRS could not show any lesions not seen on CT or MR (3). Tabarin et al emphasized that conventional imaging such as CT and MR was more helpful than SRS (2). In another study, it was stated that SRS could not find otherwise unsuspected lesions (10). On the other hand, there are some articles which emphasized the high diagnostic yield of SRS $(5,7)$. In our study, only in one patient CT was positive while SRS, which was done three years ago, was normal. SRS might be positive, if it was repeated.

It should be kept in mind that detectability of lesions in scintigraphic imaging depends on various factors such as lesion size, location, type, degree of somatostatin receptor expression and the amount of radioactivity in the lesion (9). In lesions smaller than one centimeter like pulmonary carcinoid tumors, extra attention must be paid while evaluating SRS images. For instance, performing SPECT or SPECT/CT imaging may overcome resolution problems compared to planar images. In one of our patients, planar SRS images were negative, while on SPECT images, a pathological uptake was seen in lung nodule which was $0.8 \mathrm{~cm}$ in diameter. Tabarin et al also emphasized the importance of SPECT imaging (2). With the improvement of the resolution, small lesions can be detected and especially in the organs where background activity is high, more succesful identification of the lesions can be done. We think that performing a thorax SPECT/CT imaging in the patients who have no pathologic In-111 octreotide on whole body and planar images will enable to localize small pulmonary lesions most of which will be carcinoid tumors.

It can be predicted that Ga-68 peptide imaging can also have succesful results in ectopic ACTH producing tumors, given the better resolution than In-111octreotide. In the recent years, there have been some efforts for imaging somatostatin bearing tumors with Ga-68 peptides. Several studies have reported succesful results with Ga-68 peptide imaging in neuroendocrine tumors and bronchial carcinoid tumors $(16,17,18)$. In our study, tumor of one patient was identified by Ga-68 DOTATATE PET-CT. The thorax CT which was done before PET-CT could not localize the tumor. Loli et al stated that small bronchial carcinoids sometimes could not be detected or identified because of their inner location made them look like normal vessels (8). There are also several case reports about detection of ectopic ACTH secreting tumors with Ga-68 peptide conjugates $(13,14,15)$. At this point, it should be remembered that our only false positive SRI was moderate uptake of Ga-68 DOTATATE in surrenal adenoma. More studies are needed to evaluate the efficacy of Ga-68 peptide conjugate imaging with PETCT in localizing ectopic ACTH secreting tumors.

In our study, six (75\%) of the localized tumors were pulmonary carcinoids. Tsagarakis pointed out that bronchial carcinoids were the most common cause of ectopic Cushing's syndrome (7). Due to their small size, localizing these tumors are quite difficult and as stated by Torpy et al, they constitute the majority of occult ectopic ACTH secreting tumors (6). Whereas in the literature, multiple studies most of which were case reports demonstrated ACTH producing bronchial carcinoid tumors using different radiopharmaceuticals such as In-111 octreotide, Tc 99m-ocreotide, F-18 FDG and Ga-68 DOTATATE 
$(3,4,5,7,8,9,10,12,14,19,20,21,22,23,24,25,26,27$, $28,29,30)$. Small cell lung carcinomas may also produce ACTH $(5,9,10,12)$. Therefore, while examining images for ectopic ACTH producing tumors, extra attention has to be paid to thoracic regions.

\section{Conclusion}

The localization of ectopic ACTH secreting tumors is a challenge. In-111 octreotide SRS have been used together with radiological modalities for a longtime. Ga-68 peptide conjugate imaging with PET-CT is a new promising modality for this indication. The pulmonary carcinoid tumors are responsible for the ectopic $\mathrm{ACTH}$ secretion in most of the cases. Therefore thoracic regions must be evaluated with great care in both In-111 octreotide SRS and PET-CT with Ga-68 peptide conjugates.

\section{References}

1. The adrenocortical hormones. In: Guyton AC, Hall JE (eds). The textbook of medical physiology. Philadelphia, W.B. Saunders Company; 2000;869-883.

2. Tabarin A, Valli N, Chanson P, Bachelot Y, Rohmer V, Bex-Bachellerie $V$, Catargi B, Roger P, Laurent F. Usefulness of somatostation receptor scintigraphy in patients with occult ectopic adrenocorticotropin syndrome. J Clin Endocrinol Metab 1999;84:1193-1202.

3. Ilias I, Torpy DJ, Pacak K, Mullen N, Wesley RA, Nieman LK. Cushing's syndrome due to ectopic corticotropin secretion: twenty years' experience at the National Institutes of Health. J Clin Endocrinol Metab 2005;90:4955-4462.

4. Hernández I, Espinosa-de-los-Monteros AL, Mendoza V, Cheng S, Molina M, Sosa E, Mercado M. Ectopic ACTH-secreting syndrome: a single center experience report with a high prevalence of occult tumor. Archives of Medical Research 2006;37:976-980.

5. De Herder WW, Krenning EP, Malchoff CD, Hofland LJ, Reubi JC, Kwekkeboom DJ, Oei HY, Pols HAP, Bruining HA, Nobels FRE, Lamberts SWJ. Somatostatin receptor scintigraphy: its value in tumor localization in patients with Cushing's syndrome caused by ectopic corticotropin or corticotropin-releasing hormone secretion. The American Journal of Medicine 1994;96:305-312.

6. Torpy DJ, Chen CC, Mullen N, Doppman JL, Carrasquillo JA, Chrousos GP, Nieman LK. Lack of utility of 111 In-pentetreotide scintigraphy in localizing ectopic ACTH producing tumors: followup of 18 patients. J Clin Endocrinol Metab 1999;84:1186-1192.

7. Tsagarakis S, Christoforaki M, Giannopoulou H, Rondogianni $F$, Housianakou I, Malagari C, Rontogianni D, Bellenis I, Thalassinos N. A reappraisal of the utility of somatostatin receptor scintigraphy in patients with ectopic adrenocorticotropin Cushing's syndrome. J Clin Endocrinol Metab 2003;88:4754-4758.

8. Loli P, Vignati F, Grossrubatscher E, Dalino P, Possa M, Zurleni F, Lomuscio G, Rossetti O, Ravini M, Vanzulli A, Bacchetta C, Galli C, Valente D. Management of occult adrenocorticotropin-secreting bronchial carcinoids: limits of endocrine testing and imaging techniques. J Clin Endocrinol Metab 2003;88:1029:1035.

9. Pacak K, llias I, Chen CC, Carrasquillo JA, Whatley M, Nieman LK. The role of [18F]fluorodeoxyglucose positron emission tomography and [111/ln]-diethylenetriaminepentaactate-D-Phe-pentetreotide scintigraphy in the localization of ectopic adrenocorticotropinsecreting tumors causing Cushing's syndrome. J Clin Endocrinol Metab 2004;89:2214-2221.
10. Isidori AM, Kaltsas GA, Pozza C, Frajese V, Newell-Price J, Reznek $\mathrm{RH}$, Jenkins PJ, Monson JP, Grossman AB, Besser GM. The ectopic adrenocorticotropin syndrome: clinical features, diagnosis, management, and long-term follow-up. J Clin Endocrinol Metab 2006;91:371-377.

11. Zemskova MS, Gundabolu B, Sinaii N, Chen CC, Carrasquillo JA, Whatley M, Chowdhury I, Gharib AM, Nieman LK. Utility of various functional and anatomic imaging modalities for detection of ectopic adrenocorticotropin-secreting tumors. J Clin Endocrinol Metab 2010;95:1207-1219.

12. Ejaz S, Vassilopoulou-Sellin R, Buisaidy NL, Hu MI, Waguespack SG, Jimenez C, Ying AK, Cabanillas M, Abbara M, Habra MA. Cushing syndrome secondary to ectopic adrenocorticotropic hormone secretion: the University of Texas MD Anderson Cancer Center Experience Cancer 2011;117:4381-4389.

13. Singer J, Werner F, Koch CA, Bartels M, Aigner T, Lincke T, Fasshauer M, Pascke R. Ectopic Cushing's syndrome caused by a well differentiated $\mathrm{ACTH}$-secreting neuroendocrine carcinoma of the ileum. Exp Clin Endocrinol Diabetes 2010;118:524-529.

14. Darr R, Zophel K, Eisenhofer G, Abolmaali N, Gastmeier J, Wieczorek $\mathrm{K}$, Jelinek V, Kamvissi V, Bornstein R, Hofbauer LC. Combined use of 68Ga-DOTATATE and 18F-FDG PET/CT to localize a bronchial carcinoid associated with ectopic ACTH syndrome. J Clin Endocrin Metab 2012;97:2207-2208.

15. Willhauck MJ, Popperl G, Rachinger W, Giese A, Auerhammer CJ, Spitzweg C. An unusual case of ectopic ACTH syndrome. Exp Clin Endocrinol Diabetes 2012;120:63-67.

16. Gabriel M, Decristoforo C, Kendler D, Dobrozemsky G, Heute $D$, Uprimny C, Kovacs P, Von Guggenberg E, Bale R, Virgolini IJ. 68GaDOTA-Tyr3-octreotide PET in neuroendocrine tumors: comparison with somatostatin receptor scintigraphy and CT. I Nucl Med 2007:48:508-518.

17. Srirajaskanthan R, Kayani I, Quigley AM, Soh J, Caplin ME, Bomanji J. The role of 68Ga-DOTATATE PET in patients with neuroendocrine tumors and negative or equivocal findings on $111 \mathrm{ln}$-DTPAoctreotide scintigraphy. J Nucl Med 2010;51:875-882.

18. Jindal $T$, Kumar A, Venkitaraman B, Dutta R, Kumar R. Role of 68Ga-DOTANOC PET/CT in the evaluation of primary pulmonary carcinoids. Korean J Intern Med 2010;25:386-391.

19. Vallette S, Disdier P, Morange-Ramos I, Thomas PA, Azorin JM, Jaquet $\mathrm{P}$, Weiller PJ, Brue T. Syndrome de Cushing révélateur d'un carcinoma neuroendocrine bronchique: intérét de la scintigraphie à l'octréotide. Rev Méd Interne 1997;18:138-143.

20. Briganti V, Mannelli M, La Cava G, Peri A, Meldolesi U, Masi R, Pupi A. Characterizing an ectopic secreting carcinoid with indium-111DTPA-D-Phe-pentetreotide. J Nucl Med 1997;38:711-714.

21. Matte J, Roufosse F, Rocmans P, Schoutens A, Jacobovitz D, Mockel J. Ectopic Cushing's syndrome and pulmonary carcinoid tumour identified by [111 In-DTPA-D-Phe1]octreotide. Postgrad Med J 1998:74:108-114.

22. Dall'Asta C, Santambrogio L, Castellani M, Ambrossi B. Difficulties in diagnosis and treatment of ectopic ACTH-producing tumors of the chest. European Journal of Cardio-thoracic Surgery 2002;21:149151.

23. Kishida K, Moriwaki M, Miyagawa Jl, Okita K, Kondo T, Itoh K, Umemura S, Kozawa J, Iwahashi H, Yoshizumi T, Imagawa A, Yamagata K, Maruyama T, Toyoshima H, Kurokawa E, Funahashi T, Matsuzawa Y. Successful use of 111 In-pentetrotide sccintigraphy for localizing ectopic adrenocorticotropin-producing bronchial carcinoid tumor in a patient with Cushing's syndrome. Internal Medicine 2003:42:996-1005

24. Bhatia PD, Fung $K$, Edmonds $M$, Driedger AA, Malthaner RA. A case of bronchopulmonary carcinoid tumor: the role of octreotide scanning in localization of an ectopic source of ACTH. Journal of Hospital Medicine 2006;1:312-316. 
25. Corsello SM, Fintini D, Lovicu RM, Paragliola RM, Rufini V, Simonetti G, Pontecorvi A. Ectopic ACTH syndrome due to occult bronchial carcinoid. Clin Nucl Med 2009;34:459-461.

26. Tani Y, Sugiyama T, Hirooka S, Izumiyama H, Hirata Y. Ectopic ACTH syndrome caused by bronchial carcinoid tumor indistinguishable from Cushing's disease. Endocrine Journal 2010;57:679-686.

27. Esfahani $A F$, Chavoshi $M$, Noorani $M H$, Saghari $M$, Eftekhari $M$, Beiki D, Fallahi B, Assadi M. Succesasful application of technetium$99 \mathrm{~m}$-labeled octreotide acetate scintigraphy in the detection of ectopic adrenocorticotropin-producing bronchial carcinoid lung tumor: a case report. Journal of Medical Case Reports 2010;4:323.
28. Xu H, Zhang M, Zhai G, Zhang M, Ning G, Li B. The role of integrated 18F-FDG PET/CT in identification of ectopic ACTH secretion tumors. Endocr 2009;36:385-391.

29. Moraes $A B$, Taboada GF, Carneiro MP, Neto LV, Wildemberg LEA, Madi K, Domingues RC, Gadelha MR. Utility of [18F]fluoro-2deoxy-D-glucose positron emission tomography in the localization of ectopic ACTH-secreting tumors. Pituitary 2009;12:380-383.

30. Kumar J, Spring $M$, Carroll PV, Barrington SF, Powrie JK. 18Flurodeoxyglucose positron emission tomography in the localization of ectopic ACTH-secreting neuroendocrine tumours. Clin Endocrinol (Oxf) 2006;64:371-374. 